\title{
Activities of the Commissioners of the Council on Russian Orthodox Church and the Council on Religious Faiths under the Council of People's Commissars of the USSR on the Tatar Autonomous Soviet Socialist Republic during the Great Patriotic War and Early Post-War Years
}

\author{
Ruslan R. Ibragimov ${ }^{1}$ \\ ${ }^{1}$ Kazan (Volga Region) Federal University, Kazan, Russia \\ Correspondence: Ruslan R. Ibragimov, Kazan (Volga Region) Federal University, 420008, Kazan, \\ Kremlyovskaya Street 18, Russia. E-mail: rus-ibr@inbox.ru
}

Received: June 2, 2015 Accepted: June 15, 2015 Online Published: June 29, 2015

doi:10.5539/jsd.v8n5p184 URL: http://dx.doi.org/10.5539/jsd.v8n5p184

\begin{abstract}
The significance of the present study is caused by the necessity to do a research on the experience of the relations between power structures and religious organizations in the context of civil society mobilization in the face of external threat. The study aims at the research of the activities of the Commissioners of the Council on Russian Orthodox Church and the Council on Religious faiths to the Council of People's Commissars of the USSR on the Tatar Autonomous Soviet Socialist Republic (TASSR) during the Great Patriotic War and early post-war years. Civilizational approach is the basic approach to the present research, which allowed examining the study subject along with political and socio-cultural aspects. The research resulted in definitions of the status of the abovementioned Councils' commissioners in the power structures system of the state, their official and practical functions, and legal basis of their activities. Based on the commissioners' quarterly plans and reports examination, techniques and methods of the commissioners' work under relative normalization of relations between the state and confessions in 1943-1948 were revealed. The research materials can be used in the development of training aids, practical activities of the structures implementing state's policy in the spiritual sphere.
\end{abstract}

Keywords: relations, the State and confessions, Commissioner, the Council on Russian Orthodox Church, Religious faiths, religious organizations, clergy, believers

\section{Introduction}

\subsection{Significance}

Since origin of state, religion has been an integral part of it, and played an important role in spiritual and socio-political life of society. During the whole period of historic development of the Russian State relations between the state and confessional institutions were based on different principles; general political situation in the state in certain periods was a determinant component.

During Soviet period all religions without exception were in disgrace. Relations between state authorities and believers and clergy were determined not only by official legislation acts proclaiming principles of separation of church and state, freedom of conscience and others; mostly they were based on resolutions, directives and circulars of dissimilar nature, which in their turn determined actions of local authorities on religious organizations. This was the real subject matter of religious policy.

Significance of the problem for scientific community is confirmed by works devoted to the problem which were published at various times (Odintsov, 2011; Mukhametshin, 2007; Fletcher, 1981; Nabiev, 2002; Yunusova, 1999; Pospelovskiy, 1995; Yakunin, 2002; Roy, 2000; Minnullin, 2006, and others). 


\section{Materials and Methods}

\subsection{Methodological Basis of the Study}

Civilizational and historical approaches are decided on as methodological basis for revealing and examining distinctive trends in methods and forms of implementation of religious policy of the Soviet state by authorities of the Tatar Autonomous Soviet Socialist Republic. They allowed examining the study subject in the multi aspect framework along with socio-political and socio-cultural aspects of the epoch under review.

\subsection{Source Basis of the Study}

Materials of commissioners of the Council on Religion under the Council of Ministers of the USSR on TASSR which are kept in National archive of the Republic of Tatarstan, and materials from the fund of Propaganda and campaigning department of Tatar regional committee of the Communist Party of the Soviet Union kept in the Central state archive of historic and political documentation of the Republic of Tatarstan were decided on as source basis of the study. Materials from the above mentioned funds which are mostly circulars, directives and guidelines of different level power structures allow revealing distinctive features in the work of commissioners of the Councils on Russian Orthodox Church and Religious faiths under the USSR Council of Ministers on the TASSR in the period under review.

\section{Results}

Persecution of religion carried out in the Soviet Union in 1920-1930, became impossible in time of war. That is why religious policy was reviewed towards liberalization during the Great Patriotic War. Short term normalization of relations between state and confessions in 1943-1948 resulted in the necessity to create a new authority to provide a link between government and religious organizations under new conditions due to liberalization of religious policy in the Soviet state. On that basis, the authority which was being created could not be guided by state institutions on religious affairs existing in 1920-1930 (Department 8 of People's Commissariat, in 1917-1924; All-Russian Central Executive Committee, Joint State Political Directorate, People's Commissariat of Internal Affairs, in 1924-1929; Permanent Committee on Religion under General Committee of All-Russian Central Executive Committee, in 1929-1934 Permanent Committee on Religion under General Committee of Central Executive Committee of the USSR, in 1934-1938) and institutions which discredited themselves by aggressive policy towards confessional associations. It is due to the above mentioned reason why new authority could not be directly subordinated to People's Commissariat of Internal Affairs, with a special "church" department in its structure, which was single-handedly exercising control of religious organizations since 1938, that is why it was decided to establish it under the Council of People's Commissars of the USSR.

The first step in religious policy liberalization in the Soviet state was made towards the Russian Orthodox Church. In September 1943 there was a meeting of Joseph Stalin and the bishops, where holding of Church Council and Patriarchate's own journal were authorized. Due to those events, first the Council on Russian Orthodox Church under the Council of People's Commissars of the USSR (Chairman - G.G.Karpov), and later, in May 1944- the Council on Religious faiths (Chairman - I.V.Polyanskiy) were established. Both Councils were in trust ship of ideological department of Central Committee of the Communist Party of the Soviet Union and department of religious affairs of KGB until 1991 (in 1965 the two Council were merged into a single body - the Council on Religious Affairs under the Council of Ministers of the USSR).

New structures of power aimed at providing a link between government and religious associations. For instance, direct functions of the Council on Russian Orthodox Church involved the following: "preliminary consideration of questions initiated by His Holiness Alexis the Patriarch of Moscow and All Russia and requiring authorization of the USSR government" (Natsional'niy arkhiv Respubliki Tatarstan, fond P-873, opis' 1, delo 1, list 7). Much attention in Council's activities was paid to the development of draft laws and resolutions on the condition of religious organizations, and various guidelines and instructions (Natsional'niy arkhiv Respubliki Tatarstan, fond P-873, opis' 1, delo 1, list 8).

After Central bodies of the Councils were formed, their commissioners in the majority of union, autonomous republics, regions and districts were appointed. On order of V.M. Molotov, Chairman of the Council of People's Commissars of USSR of March, 29, 1945 the commissioners' status was equaled to the status of Heads of Departments of union, autonomous republics. Commissioners' functions and sphere of activities were approved by Regulations on the Councils. In particular, according to Regulations on the Council on Russian Orthodox Church, its commissioners were to "supervise correct and timely implementation of USSR laws and resolutions of the USSR government concerning the Russian Orthodox Church: sending conclusions on Russian Orthodox 
Church affairs to the Council of People's Commissars of USSR; general accounting of churches and drawing up statistical summary reports based on data given by local authorities" (Natsional'niy arkhiv Respubliki Tatarstan, fond P-873, opis' 1, delo 1, list 8). Thus, commissioners were assigned to become workforce and conductors of religious policy of the Soviet state at the local level.

In their work commissioners were governed by laws and government's resolutions on religion. At the initial stage of commissioners' work basic documents were: The Decree of January, 231918 "On separation of Church and State, and School and Church"; relevant articles of the USSR Constitution; resolutions of All-Russian Central Executive Committee and Council of People's Commissars of Russian Soviet Federative Socialist Republic of April, 8 1929; Regulations on the Councils on Russian Orthodox Church and Religious faiths under the Council of People's Commissars of the USSR, and resolutions of the Council of People's Commissars of the USSR of November, 281943 concerning the procedure for opening of churches.

The primary objective of commissioners' initial stage activities was restoration of accounting for religious communities and groups, receiving and examining petitions on registration of religious associations and opening of relevant houses of prayer. In terms of officially operating abovementioned communities and groups, commissioners' work was significantly "simplified" by the previous religious policy. For instance, according to commissioner of the Council on Russian Orthodox Church under the Council of People's Commissars of the USSR on the TASSR F.F. Gorbachyov, by June, 301944 there were only two officially operating Russian Orthodox associations: in Kazan and Menzelinsk.

With all questions concerning the sphere of state-confessions relations, as registration of religious communities and houses of prayer, organizing religious holidays; believers contacted the commissioner in a certain region. As a rule, commissioners' work was based on quarterly and six-monthly plans. Here is a work plan for second half of year 1947 of commissioner of the Council on Religious faiths under the Council of Ministers of the USSR on the TASSR Bagaev: "From July, 1 to November, 201947 to inspect the following regions ... (which regions are meant is not mentioned in the document - Ibragimov R.R.). While inspecting to pay attention to the following questions:

1) Examine facts of the Soviet legislation violations concerning religious faiths by religious workers, activists, and by local authorities (unauthorized opening and closing of houses of prayer, etc)". 2) Examine activities of operating religious communities, religious workers, executive body of revision commissions, amount of believers (approximately), attending mosques on Fridays, Eid-al-Fitr, Eid-al-Adha. 3) Going through religious rites during the Sawm: violation of work discipline during the Sawm; Sacrificial offerings, the involvement of women in religious movement; children going through religious rites; burial rites, "Isem kushu" (Tatar Muslim rite for naming a child), Nikah, visiting Holy sites. 4) Examine activities of travelling mullahs, sphere of their activities, number, taxing, etc. 5) Examine illegally operating religious communities; places where they have their services, those who officiate, amount of believers (approximately)" (Natsional'niy arkhiv Respubliki Tatarstan, fond P-873, opis' 1, delo 3, list 63). Prevailence of words like "examine, investigate" in the text shows that commissioners did not mean to provide a link between government and religious associations, but exercise control over the latter. As it can be seen from points 4 and 5, not only officially operating, but also unregistered illegal religious communities and groups were within the scope of commissioners' professional activities. Thus, since the beginning of commissioners' work, there was a certain amount of fairness in their methods, in terms of sober estimation of population's religious activity. It was significantly different from official position of the Soviet state in this issue, made public by mass media and taking into account only registered religious associations and number of official clergy. Under totalitarian regime, data on number and activities of the latter were not made public.

Commissioners drew up special statements on big religious holidays: Eid-al-Fitr, Eid-al-Adha (Muslim); Easter (Orthodox). According to one of the statements, during Eid-al-Fitr celebration in 1949 in Kazan: "700-800 people attended mosque for Taraweeh prayer, including 100-150 women. Up to 1500 believers, including 300-400 women, attended on Laylat al-Qadr (Night of Destiny). Up to 1000 believers attended mosque for Jumma (Friday) prayer, 60000 rubles of Sadaqah (voluntary charity) was raised" (Natsional'niy arkhiv Respubliki Tatarstan, fond P-873, opis' 1, delo 4, list 65). Just before the abovementioned holidays commissioners were given detailed guidelines on main aspects which require consideration. Among others, there always was a point concerning control over religious activity of women, as women historically played an important role in bringing up children and developing certain spiritual values in them. Speaking about commissioners' reports, it should be noted that they are a valuable source of data, allowing to examine state-confessions relations in several aspects: relations between central and local authorities concerning religious policy, contacts between religious associations and authorities, statistics on amount of believers and clergy, 
dynamics in quantity of registered and illegally operating religious associations (approximately) etc.

It should be taken into account, that owing to specific character of rituals in Islam, commissioners' reports could not show the real degree of religiousness among Muslim population of the republic. Since late 1920s, the start of aggressive anti-Islamic policy of the Soviet state, religious life of Tatars was focused on the family, where the generation, which had had a comprehensive Muslim education before the revolution, continued their knowledge and values of Islam to the generations, whose outlook was formed under massive propaganda of atheism. Despite the fact that, the Soviet state was exercising control over citizens in all spheres of life, it was rather difficult to do the same on the family level; Friday and Holy Day prayers were taking place in a covert form, and looked like a usual family and friends gatherings at home. Within this framework, the amount of Muslim communities (registered and operating illegally), amount of believers, their gender and age, amount of Tatars keeping rituals of Islam - all these factors, used by commissioners of the Council on Religious Affairs in estimating the degree of religiousness among Tatars, can be considered fairly relative.

The Council commissioners were authorized to recruit and appoint the clergy people. According to the Charter of Spiritual Directorate of the Muslims, filling vacancies, disgowning and displacement of the clergy were a sole responsibility of Spiritual Directorates. Before one or another religious community introduced their candidate for a religious worker, they were to obtain approval from commissioner, who in his turn, was to notify a commissioner of the Council on the republic, region, or district the center of Spiritual Directorate belonged to. It should be added that, there was a stringent restriction of information by the State, it applied to basic documents as well. For instance, the resolution of the Council of People's Commissars of the USSR of November, 281943 "Concerning the procedure for opening of churches", "...not having been published for general public" (Natsional'niy arkhiv Respubliki Tatarstan, fond P-873, opis' 1, delo 2, list 3), could not be laid open to clergy or believers.

First steps of the Soviet government, signalizing years of the Thaw, in State-confessions relations were greatly supported by believers. Firstly, it resulted in religious communities' and groups' petitions on official registration. For instance, in the year 1944, there were 46 petitions made by Orthodox communities of the republic only. That is why, since the establishment of commissioners' institution, considering believers' petitions on registration of religious communities and houses of prayer became main sphere of their activities. Decision making procedure in this issue was multi-level. District and city Councils of workers' deputies, without making a decision, forwarded believers' petitions on opening a house of prayer together with support documentation to the commissioner of the Council of Religious Affairs of the relevant district, region, or republic. He carried out all the work regarding acceptance, registration, and preliminary consideration of the petitions, checkup, and drawing up conclusions. Religious center's (in the TASSR - Diocesan administration) view on the possibility of opening a house of prayer was taken in making a decision. After that, all the documents were considered in the Council of People's Commissars (since 1946 - Council of Ministers) of the districts, regions, union and autonomous republics, where the only possible decision was rejection of the petition. If local Councils of People's Commissars chose to grant a petition, the latter together with the Councils of People's Commissars' conclusion was forwarded to the relevant Council (on Russian Orthodox Church, or Religious faiths under the Councils of People's Commissars of the USSR) for making a final decision.

Later, the procedure for opening houses of prayer and religious communities was altered. According to the resolution of the Council of Ministers of the USSR of February, $17^{\text {th }} 1955$, final decision making on the believers' petitions on opening of the abovementioned buildings and communities was placed upon the Councils of Ministers of union republics in coordination with the Councils on Russian Orthodox Church and Religious faiths.

At the initial stage of commissioners' activities there were significant difficulties in determining rights and responsibilities of the latter in the structure of district, regional, and republican authorities. There were cases when commissioners had to exercise functions which had nothing in common with their direct responsibilities. Particularly, Party authorities of the TASSR due to lack of personnel used to send commissioners on mission trips in the republic "...to mend a situation with combined harvester-thresher maintenance" (Natsional'niy arkhiv Respubliki Tatarstan, fond P-873, opis' 1, delo 2, list 7) etc. At the same time, the reality was that in order to fulfill their direct functions and planned activities, commissioners were to go on mission trips at least once in a month. That was a key factor for examining the actions of believers and clergy, and drawing up conclusions on one or another issue. According to commissioner of the Council on Religious faiths on the TASSR Kh.S. Bagaev, “... we will never keep our 'religious facilities' in order without going on mission trips... according to my plan, in the year 1946 I was to visit 12-15 places where my help was needed... if local bodies agree on my plan, then in 1946 'religious facilities' of the TASSR will mainly be well organized" (Tsentral'niy gosudarstvenniy arkhiv 
istoriko-politicheskoy dokumentatsii Respubliki Tatarstan, fond P-873, opis' 5, delo 18446, list 3).

The commissioner used term "religious facilities" to denote believers, clergy, and houses of prayer. It is hard to escape a conclusion that this official takes religious sphere for some kind of manufacturing facilities, while work with those who belong to such subtle matter as religion involves better flexibility and delicacy. Besides, it is not quite clear why local authorities were to agree on his work plan. There might have been some misunderstanding of commissioner's place in the power structures, because commissioners worked under local Council of Ministers, and were directly subordinated to Chairmen of Councils on Russian Orthodox Church and Religious faiths under Council of Ministers of the USSR.

Speaking about work methods of first commissioners of the Councils on Russian Orthodox Church and Religious faiths on the TASSR, it should be noted that they were rather fair in the assessment of the religious situation in the republic. One example of it was their aim to register some practically operating religious organizations which insisted on being legalized and unconditionally recognized the Soviet laws on Religion. If so, it could be possible to get more correct information about degree of religiousness among population, it would be much easier to exercise control over religious organizations, and religious situation in whole. But superior authorities, namely the Council of Ministers of the TASSR and Councils on Russian Orthodox Church and Religious faiths were not willing to make such decisions, because their wide usage meant inevitable rise of the amount of registered religious organizations, the number of which was the main indicator of religious activity of population for Soviet propaganda, that is why such actions of authorities were impossible even in the period of the most non-judgmental attitude of the state towards religion, although in exceptional circumstances they sometimes were allowed for.

Since start of commissioners' work, significant attention was paid to examining preaching activities of the clergy among believers. This component of religious life was considered by Soviet authorities the most powerful lever on believers. Depending on how strongly they glorified the Party and government (it was impossible to avoid it under existing situation), or were moderate in advocating for them, believers' attitude to Soviet power, the degree of their loyalty or disapproval of the latter depended on. That is why this aspect of work was important for commissioners not only during big religious holidays, but also during the whole covered period.

The distinctive feature of work of commissioners of Councils on Russian Orthodox Church and Religious faiths, compared to work principles of their pre-war predecessors, was the fact that they exercised control over implementation of laws on religion not only in the context of religious communities and groups, but also city and district executive committees of the working people, which was rather rare for the period of 1920-1930. There were cases during the period under review when this aspect of commissioners' work was a separate paragraph in their quarterly work plans. In particular, work plan of the commissioner of the Council on Russian Orthodox Church under the Council of Ministers of the USSR on the TASSR F.F.Gorbachyov for the second quarter of the year 1948 provided for "Examining the reasons for interference of the local authorities into the life of Church and facts of violations of the USSR government resolutions on Church" (Natsional'niy arkhiv Respubliki Tatarstan, fond P-873, opis' 1, delo 3, list 84). These aspects were peculiar only to the first commissioners' work. Later, due to change of religious policy, these aspects of work were replaced by others which meant to control only religious side of the relations between temporal powers and confessional communities and groups.

In the TASSR disagreements between party and state bodies (on the local level) on the one side, and commissioners on the other side, were on such important issue as granting a petition of one or another religious community, when the commissioner considered it possible and in some cases even necessary to register the religious community. For instance, in the period 1945-1947 a significant amount of orthodox believers insistently petitioned for opening church in the town of Elabuga, and villages Verkhnyaya Karmalka, Pervomaiskiy district, (now - Cheremshanskiy district), Karmaly, Sheremet'evskiy district (now Nizhnekamskiy district), Chinchurino, Tetyushskiy district. The petitiones were supported by Archbishop of Kazan Germogen and His Holiness Alexis the Patriarch of Moscow and All Russia; whose opinions were approved of by the Chairman of the Council on Russian Orthodox Church under the Council of Ministers of the USSR G.G.Karpov, and Deputy Chairman of the Council of Ministers of the USSR A.N.Kosygin. Nevertheless, in March 1946, the commissioner of the given Council on the TASSR F.F. Gorbachyov wrote in his memo to G.G.Karpov: “...Comrade Sharafeev (Chairman of Council of Ministers of the TASSR) directly stated that "no one addressed to me with these issues, I will not consider them until there is an approval of Comrade Muratov. (First Secretary of TASSR regional committee) When you are received by Comrade Muratov, you have to leave without your issues resolved due to a single cause, that "...we will not be enthusiastic about it, and there still have not been any complaints about our actions" (Natsional'niy arkhiv Respubliki Tatarstan, fond P-873, opis' 1, delo 2, list 40). According to the abovementioned facts, contrary to the imprescriptible law of administrative 
system, under which the "recommendations" of central authorities to local ones meant their obligatory implementation by the latter, in some cases the decision on registration of one or another religious community or group was at the discretion of local authorities.

Similar was the situation with the petition of Muslims from Kirovskiy distcrict of Kazan on registration of the religious community and opening a mosque on its territory at the address Bol'shaya Street, 63. By mid 1940s, three Muslim communities had been formed in this district. According to commissioner of the Council on Religious faiths on the TASSR Kh.S.Bagaev, it would be appropriate to open a mosque at the abovementioned address and register one of the communities, after which the three communities would merge together. But commissioner's offer was not supported by local authorities.

The end of short-term liberal line in religious policy in 1948 was expressed in the circular letter of the Council on Religious faiths, ordaining the commissioners to stop granting petitions on registration of religious communities. "The rise of religious sentiments apparently was unexpected to the authorities, and caused a reasonable response from the governmental bodies in Moscow" (Yunusova A.B. Islam v Bashkortostane, Ufa: 1999.p.239). The tightening of religious policy in the TASSR resulted in blamestorming for "mistakes" made in the period of Thaw in state -religion relations. Commissioners of the Council on Russian Orthodox Church and Religious faiths were found responsible for the mistakes in the TASSR. The reason for invoking investigation was strong: in the night from $7^{\text {th }}$ to $8^{\text {th }}$ of July 1949after mass praying, the Orthodox believers from village Semiozyorka, Yudinskiy district made attempts to arrange Cross Procession to Kazan. According to Bureau of Regional Committee of the TASSR, the person to be blamed for this "incident" was the commissioner of the abovementioned Council under the Council of Ministers on the TASSR F.F.Gorbachyov. Besides accusations of the abovementioned incident, the commissioner was also accused of "...not helping to implement the party and government directives on Church, and even more than that, of strengthening the clerics activities by his inaction and unprincipled approach to dealing with certain issues" (Tsentral'niy gosudarstvenniy arkhiv istoriko-politicheskoy dokumentatsii Respubliki Tatarstan, fond 15, opis' 9, delo 6, list 70). On this basis, the Bureau of Regional Committee of the All Union Communist Party of the Bolsheviks resolved "... to discharge F.F.Gorbachyov and issue a reprimand placed in his engagement file" (Tsentral'niy gosudarstvenniy arkhiv istoriko-politicheskoy dokumentatsii Respubliki Tatarstan, fond 15, opis' 9, delo 6, list 70).

Political situation in the country and activities inspections of administrative officials who were to provide "a link between the government and religious organizations in the TASSR, meant inspecting the activities of commissioner of the Council on Religious faiths under the Council of Ministers on the TASSR Kh.S.Bagaev. Such mistakes and defects as "...indifference to the activities of unregistered mullahs and other religious workers...in resolving issues, determining our attitude to religion and the clergy he showed political apathy, and in some cases was the aider of mullahs and leaders of other religious communities" (Tsentral'niy gosudarstvenniy arkhiv istoriko-politicheskoy dokumentatsii Respubliki Tatarstan, fond 15, opis' 9, delo 6, list 165). Such inspection results determined the following resolution of Bureau of Regional Committee of the All Union Communist Party of the Bolsheviks: "For letting down the Bolshevist vigilance, to dismiss Comrade Bagaev and issue a reprimand placed in his engagement file" (Tsentral'niy gosudarstvenniy arkhiv istoriko-politicheskoy dokumentatsii Respubliki Tatarstan, fond 15, opis' 9, delo 6, list 165).

\section{Discussions}

Presently, the problem of state-confessions relations in the Soviet State is the study subject for Russian and foreign researchers and scientific centers. Within the framework of investigations, events of the past are reconstructed, which makes it possible to estimate methods and techniques of religious policy implementation by the state with the help of modern scientific approaches and methods; as well as to estimate processes within confessional communities. Examining authorities' activities, which due to their objectives directly contacted to religious organizations, takes specific place in these investigations; the authorities are: the Council on Russian Orthodox Church under the Council of People's Commissars (Council of Ministers) of the USSR and the Council on Religious faiths under the Council of People's Commissars (Council of Ministers) of the USSR and their staff of commissioners in regions, districts, and republics of the country. Tendencies in the Soviet policy towards believers and clergy were reflected in the style and approaches of these commissioners' work.

\section{Conclusion}

As can be seen from above, the analysis of the activities of commissioners of the Council on Russian Orthodox Church and the Council on Religious faiths under the Council of Ministers of the USSR on the TASSR, allows to state that although these structures were officially created for providing a link between the authorities and religious community, their main function was exercising control over the latter. The specific feature of first 
commissioners' work in the TASSR was their fair attitude towards the needs of believers and clergy, which was considered as derogation from general line of the party in Religion by superior authorities.

\section{Acknowledgments}

The work is performed according to the Russian Government Program of Competitive Growth of Kazan Federal University.

\section{References}

Centralniy arhiv istoriko-politicheskoy dokumentatsii Respubliki Tatarstan. Fond. 15. Opis.5. Delo, 1844b.

Centralniy arhiv istoriko-politicheskoy dokumentatsii Respubliki Tatarstan. Fond. 15. Opis.9. Delo, 6.

Fletcher, W. (1981). Soviet believers. The religious sector of the population. Lawrence.

Minnullin, I. R. (2006). Musul'manskoe duhovenstvo i vlas't v Tatarstane, 1920-1930-y gg. Kazan: Institut Istorii im.Sh.Mardjani AN RT.

Mukhametshin, R. M. (2007). Islam v Tatarstane. Moskva: Logos.

Nabiyev, R. A. (2002). Islam i gosudarstvo: kulturnaya i istoricheskaya evolutsiya musul'manskoy religii na Evropeyskom Vostoke. Kazan: Izdatelstvo Kazanskogo universiteta.

Natsionalniy arhiv Respubliki Tatarstan. Fond. R-873. Opis.1. Delo, 1.

Natsionalniy arhiv Respubliki Tatarstan. Fond. R-873. Opis.1. Delo, 2.

Natsionalniy arhiv Respubliki Tatarstan. Fond. R-873. Opis.1. Delo, 3.

Natsionalniy arhiv Respubliki Tatarstan. Fond. R-873. Opis.1. Delo, 4.

Odintsov, M. I. (2011). Zapisi besed predsedateley Soveta po delam Russkoy pravoslavnoy cerkvy pri SNK SSSR G.G.Karpova i V.A. Kuroedova s patriarkhami Russkoy pravoslavnoy tserkvi (1943-1961 gg.). Moskva: Knigniy dom «LIBRIKOM».

Pospelovsky, D. V. (1995). Russkaya pravoslavnaya tserkov'v XX veke. Moskva: Respublika.

Roy, Ya. (2000). Islam in the Soviet Union: From the Second World War to Gorbachev. New York: Columbia University Press.

Yakunin, V. N. (2002). Pravovoy status, polozhenie, deyatel'nost, vneshnie svyazi Russkoy Pravoslavnoy tserkvi v gody Velikoy Otechestvennoy voyny, 1941-1945 gg. (Doktorskaya disserttsiya).

Yunusova, A. B. (1999). Islam v Bashkortostane. Ufa: Ufimsky poligrafkombinat.

\section{Copyrights}

Copyright for this article is retained by the author(s), with first publication rights granted to the journal.

This is an open-access article distributed under the terms and conditions of the Creative Commons Attribution license (http://creativecommons.org/licenses/by/3.0/). 